\title{
The pustulated temnospondyl revisited, a plagiosternine plagiosaurid from the Lower Triassic of Brazil
}

\author{
Sérgio Dias-Da-Silva and Andrew R. Milner \\ Acta Palaeontologica Polonica 55 (3), 2010: 561-563 doi: http://dx.doi.org/10.4202/app.2009.0131
}

A recent contribution published in this journal (Dias-da-Silva and Ilha 2009) reported a dermal skull fragment indicating the presence of a putative plagiosauroid temnospondyl in the Lower Triassic Sanga do Cabral Formation of the Paraná Basin, Southern Brazil. The taxonomic assignation of this specimen was necessarily tentative as it was based on circumstantial evidence, specifically the presence of a dense pustular ornamentation over four partial dermal skull bones, consideration of the described taxa known to bear such ornamentation, and the stratigraphic and paleobiogeographic range of such taxa. Therefore, Dias-da-Silva and Ilha (2009) could not be totally certain about the plagiosauroid affinities of the new specimen and ascribed it to ?Plagiosauridae. It was particularly difficult to make a precise osteological identification of the specimen and six alternative osteological interpretations were made in comparison to both Gerrothorax and Peltobatrachus (see Dias-da-Silva and Ilha 2009: fig. 2). In spite of the poor taxonomic resolution, the new specimen raised interesting questions regarding the presence of plagiosauroid stereospondyls in western Gondwana, as well as their evolutionary patterns, biostratigraphic and paleobiogeographic implications. After Dias-da-Silva and Ilha's (2009) contribution was published, new data from Damiani et al. (2009) raised the possibility of narrowing down the taxonomic identity of the plagiosauroid from Brazil. Accordingly, this brief report provides a more precise taxonomic assignation for this material.

Sérgio Dias-da-Silva [sergiosilva@ unipampa.edu.br], Laboratório de Paleobiologia, Campus de São Gabriel, Universidade Federal do Pampa, Avenida Antônio Trilha, 1847, Bairro Centro, CEP 97.300-000, São Gabriel,

Rio Grande do Sul, Brazil (corresponding author); Andrew R. Milner [andrew.milner@ nhm.ac.uk], Department of Palaeontology, The Natural History Museum, Cromwell Road, London, SW7 5BD, United Kingdom.

This is an open-access article distributed under the terms of the Creative Commons 
Attribution License (for details please see creativecommons.org), which permits unrestricted use, distribution, and reproduction in any medium, provided the original author and source are credited.

PoFif Full text $(135.4 \mathrm{kB})$ 